\title{
Prognostic value of NT-proBNP in patients with severe COVID-19
}

\author{
Lei Gao ${ }^{1 \dagger}$, Dan Jiang ${ }^{2 \dagger}$, Xue-song Wen ${ }^{1}$, Xiao-cheng Cheng ${ }^{1}$, Min Sun ${ }^{1}$, Bin He', Lin-na You', Peng Lei', \\ Xiao-wei Tan', Shu Qin', Guo-qiang Cai ${ }^{1,3^{*}}$ and Dong-ying Zhang ${ }^{1 *}$
}

\begin{abstract}
Background: The outbreak of coronavirus disease 2019 (COVID-19) caused by severe acute respiratory syndrome coronavirus 2 (SARS-CoV-2) in China has been declared a public health emergency of international concern. The cardiac injury is a common condition among the hospitalized patients with COVID-19. However, whether N terminal pro B type natriuretic peptide (NT-proBNP) predicted outcome of severe COVID-19 patients was unknown.

Methods: The study initially enrolled 102 patients with severe COVID-19 from a continuous sample. After screening out the ineligible cases, 54 patients were analyzed in this study. The primary outcome was in-hospital death defined as the case fatality rate. Research information and following-up data were obtained from their medical records.

Results: The best cut-off value of NT-proBNP for predicting in-hospital death was $88.64 \mathrm{pg} / \mathrm{mL}$ with the sensitivity for $100 \%$ and the specificity for $66.67 \%$. Patients with high NT-proBNP values (>88.64 pg/mL) had a significantly increased risk of death during the days of following-up compared with those with low values ( $\leq 88.64 \mathrm{pg} / \mathrm{mL}$ ). After adjustment for potential risk factors, NT-proBNP was independently correlated with in-hospital death.
\end{abstract}

Conclusion: NT-proBNP might be an independent risk factor for in-hospital death in patients with severe COVID-19. Trial registration: ClinicalTrials, NCT04292964. Registered 03 March 2020,

Keywords: NT-proBNT, COVID-19, SARS-CoV-2, Outcome

\section{Background}

The outbreak of coronavirus disease 2019 (COVID-19) caused by severe acute respiratory syndrome coronavirus 2 (SARS-CoV-2) in China has been declared a public health emergency of international concern on 30 January 2020 [1]. Despite lower case fatality rate, SARS-CoV-2 has killed more people than SARS and MERS and the number keeps growing [2]. Epidemic studies have described that patients with severe COVID-19 were more likely to develop adverse clinical outcomes with more

\footnotetext{
* Correspondence: 185161439@qq.com; zhangdongying@cqmu.edu.com ${ }^{\dagger}$ Lei Gao and Dan Jiang contributed equally to this work.

${ }^{1}$ Department of Cardiovascular Medicine, The First Affiliated Hospital of Chongqing Medical University, Chongqing 400016, China

Full list of author information is available at the end of the article
}

complications including acute respiratory distress syndrome, acute cardiac injury, acute kidney injury and shock [3, 4]. Investigating prognostic markers for severe patients provides insights for early therapeutic strategies.

Cardiac injury is a common condition among the hospitalized patients with COVID-19. It was recently reported that $19.7 \%$ patients from a total of 416 cases with COVID-19 had cardiac injury with more adverse clinical outcomes compared to those without cardiac injury [5]. Guo et al. also reported that COVID-19 patients with elevated TnT levels had higher mortality [6]. A retrospective, single-center case series of the 138 COVID-19 patients study reported that 7.2 and $16.7 \%$ patients had complications of acute cardiac injury and arrhythmia, respectively [7]. The fraction of acute cardiac injury and

(c) The Author(s). 2020 Open Access This article is licensed under a Creative Commons Attribution 4.0 International License, which permits use, sharing, adaptation, distribution and reproduction in any medium or format, as long as you give appropriate credit to the original author(s) and the source, provide a link to the Creative Commons licence, and indicate if changes were made. The images or other third party material in this article are included in the article's Creative Commons licence, unless indicated otherwise in a credit line to the material. If material is not included in the article's Creative Commons licence and your intended use is not permitted by statutory regulation or exceeds the permitted use, you will need to obtain permission directly from the copyright holder. To view a copy of this licence, visit http://creativecommons.org/licenses/by/4.0/ The Creative Commons Public Domain Dedication waiver (http://creativecommons.org/publicdomain/zero/1.0/) applies to the data made available in this article, unless otherwise stated in a credit line to the data. 
arrhythmia was even higher in severe patients with the percentage of 22.2 and $44.4 \%$, respectively. The patients with severe COVID-19 also showed higher creatine kinase-MB (CK-MB) and hypersensitive troponin I (hsTnI) levels than others [7].

A recent study demonstrated that the heart failure marker, $\mathrm{N}$ terminal pro $\mathrm{B}$ type natriuretic peptide (NTproBNP), increased significantly during the course of hospitalization in those who ultimately died [6]. However, there is no research concerning whether NTproBNP predicted the outcome of severe COVID-19 patients.

\section{Methods}

\section{Subjects}

The study initially enrolled 102 patients with severe COVID-19 from a continuous sample in Hubei General Hospital during the management by national medical team. The study is a retrospective, observational registry with clinicaltrials.gov identifier NCT04292964. The study was also registered on Chinese medical research registration information system. All procedures were followed the instructions of local ethic committee (approval NO. 20200701). Criteria for severe conditions included respiratory rate $\geq 30 / \mathrm{min}$ or rest oxyhemoglobin saturation $\left(\mathrm{SPO}_{2}\right) \leq 93 \%$ or oxygenation index (arterial oxygen tension/ inspired oxygen fraction, $\mathrm{PaO} 2 /$ $\mathrm{FiO} 2) \leq 300 \mathrm{mmHg}$. All the data was collected using a same protocol by well-trained researchers with a doubleblind method. Patients lacking NT-proBNP results $(n=$ $45)$ were excluded. Patients who had stroke $(n=2)$ and acute myocardial infarction $(n=1)$ were excluded. Other exclusion criteria including patients with malignant tumor $(n=0)$ and pregnancy $(n=0)$ were also taken account. Finally, 54 patients with COVID-19 were studied in this research.

\section{Baseline data and follow-up}

Demographic data, clinical features and medical history were available and collected according to the patient record system. Data collection of laboratory results were defined using the first-time examination at admission (within $24 \mathrm{~h}$ after admission). All the laboratory data was tested in a same laboratory with the same standard. To observe the risk of in-hospital death, patients were followed up from admission to discharge (1 to 15 days). The primary outcome was in-hospital death defined as the case fatality rate. The follow-up data were collected from reviewing medical records by trained researchers using double-blind method.

\section{Statistical analysis}

Data is presented as mean \pm standard deviation, frequency (\%) or median (interquartile ranges). Intergroup comparisons between NT-proBNP high group and low group were made by the independent-samples $T$-test (normally distributed continuous variables), MannWhitney $U$ test (nonnormally distributed continuous variables) and chi-square test (categorical variables). The best NT-proBNP cut-off was that of the highest product of sensitivity and specificity for in-hospital death prediction. Cumulative survival curves of in-hospital death were estimated using the Kaplan-Meier product-limit estimation method with the log-rank test. Spearman correlation analysis was used to investigate the coefficients of NT-proBNP with selected covariates. Cox proportional hazards models were used to screening out the potential risk factors and analyzing the independent effect of NT-proBNP for in-hospital death. Statistical analyses were performed by SPSS 22.0 (SPSS, Chicago, IL, USA) and a two-sided $P<0.05$ was considered statistically significant.

\section{Results \\ Baseline characteristics}

Baseline characteristics of participants were divided into two groups by low and high NT-proBNP levels (NT-proBNP $\leq 88.64 \mathrm{pg} / \mathrm{mL}$ and NT-proBNP> $88.64 \mathrm{pg} /$ $\mathrm{mL}$, Table 1) according to the cut-off value determined in the ROC curve (Fig. 1). Patients in NTproBNP high group were significantly older with more comorbidities of hypertension (HP) and coronary heart disease (CHD), higher levels of diastolic blood pressure (DBP), myohemoglobin (MYO), CK$\mathrm{MB}$, hs-TnI, blood urea, creatinine, white blood cell (WBC), C-Reactive Protein (CRP) and procalcitonin (PCT) and lower level of lymphocyte (LYM) than the participants in NT-proBNP low group. Other characteristics like sex, temperature, pulse rate, respiratory rate, systolic blood pressure and the history of chronic obstructive pulmonary disease (COPD) and diabetes showed no significance between two groups with the different levels of NT-proBNP (Table 1.).

\section{Receiver operator characteristic (ROC) curve for prediction in-hospital death}

Receiver operation characteristic (ROC) curves were shown in Fig. 1 to analyze the prognostic value and the best cut-off of NT-proBNP for prediction in-hospital death. The area under the curve (AUC) for in-hospital death was 0.909 (95\%CI $0.799-0.970, P<0.001)$. The best cut-off of NT-proBNP for predicting in-hospital death was $88.64 \mathrm{pg} / \mathrm{mL}$ with the sensitivity for $100 \%$ and the specificity for $66.67 \%$ (Fig. 1).

\section{Cumulative survival curves of in-hospital death}

Cumulative survival rate curves between two groups categorized by NT-proBNP cut-off value were shown in 
Table 1 Baseline characteristics of total and different degrees of NT-proBNP

\begin{tabular}{|c|c|c|c|c|}
\hline Characteristics & Total $(n=54)$ & NT-proBNP $\leq 88.64 \mathrm{pg} / \mathrm{ml}(n=24)$ & NT-proBNP> 88.64 pg/ml $(n=30)$ & $P$ \\
\hline Male/Female (n) & $24 / 30$ & $8 / 16$ & $16 / 14$ & 0.142 \\
\hline Age (years) & $60.4 \pm 16.1$ & $51.6 \pm 13.9$ & $67.4 \pm 14.4$ & $<0.001$ \\
\hline Temperature $\left({ }^{\circ} \mathrm{C}\right)$ & $36.7(36.5-36.9)$ & $36.8(36.5-36.9)$ & $36.6(36.5-36.9)$ & 0.670 \\
\hline Pulse (/min) & $82(76-97)$ & $84(76-97)$ & $82(76-96)$ & 0.679 \\
\hline Respire (/min) & $20(19-21)$ & $20(19-20)$ & $20(18-26)$ & 0.209 \\
\hline SBP $(\mathrm{mmHg})$ & $128(119-138)$ & $126(115-134)$ & $129(120-144)$ & 0.218 \\
\hline $\mathrm{DBP}(\mathrm{mmHg})$ & $78(70-83)$ & $73(69-78)$ & $80(70-86)$ & 0.040 \\
\hline History of HP (n) & $12(22.2 \%)$ & $2(8.3 \%)$ & $10(33.3 \%)$ & 0.028 \\
\hline History of CHD (n) & $9(16.7 \%)$ & $1(4.2 \%)$ & $8(26.7 \%)$ & 0.027 \\
\hline History of COPD (n) & $2(3.7 \%)$ & 0 & $2(6.7 \%)$ & 0.197 \\
\hline History of DM (n) & $8(14.8 \%)$ & $3(12.5 \%)$ & $5(16.7 \%)$ & 0.668 \\
\hline NT-proBNP (pg/ml) & 137.30 (39.64-494.98) & $37.28(22.28-61.74)$ & 420.40 (199.63-919.88) & $<0.001$ \\
\hline MYO (ng/ml) & $39.28(26.26-86.84)$ & 25.35 (14.04-35.20) & 82.53 (34.55-123.96) & $<0.001$ \\
\hline CK-MB (ug/L) & $1.04(0.65-2.27)$ & $0.63(0.37-0.79)$ & $1.90(1.08-3.78)$ & $<0.001$ \\
\hline Hs-Tnl (ng/ml) & $<0.006(<0.006-0.022)$ & $<0.006(<0.006-<0.006)$ & $0.021(<0.006-0.136)$ & 0.001 \\
\hline Urea (mmol/L) & $4.8(3.3-9.0)$ & $3.4(2.6-4.9)$ & $7.1(4.4-9.9)$ & $<0.001$ \\
\hline Creatinine (umol/L) & $63(44-77)$ & $54(41-69)$ & $79(55-86)$ & 0.016 \\
\hline WBC $\left(10^{9} / \mathrm{L}\right)$ & $5.42(4.13-7.45)$ & $5.89(4.53-10.76)$ & $5.73(4.50-8.20)$ & 0.007 \\
\hline $\operatorname{LYM}\left(10^{9} / \mathrm{L}\right)$ & $1.12 \pm 0.52$ & $1.30 \pm 0.43$ & $0.98 \pm 0.55$ & 0.021 \\
\hline CRP (mg/L) & $34.8(5.3-61.0)$ & $7.6(5.0-34.8)$ & $54.3(14.3-117.9)$ & 0.003 \\
\hline PCT (ng/ml) & $0.063(0.029-0.171)$ & $0.038(0.020-0.058)$ & $0.137(0.049-0.468)$ & $<0.001$ \\
\hline In-hospital death (n) & $18(33.3 \%)$ & 0 & $18(60.0 \%)$ & $<0.001$ \\
\hline
\end{tabular}

Abbreviations: SBP Systolic blood pressure, DBP Diastolic blood pressure, HP Hypertension, CHD Coronary heart disease, COPD Chronic obstructive pulmonary disease, DM Diabetes mellitus, NT-proBNP N-terminal pro-brain natriuretic peptide, MYO Myoglobin, CK-MB creatine kinase-MB, Hs-Tn/ High-sensitivity troponin-I, WBC White blood cell, LYM Lymphocytes, CRP C-reactive protein, PCT Procalcitonin

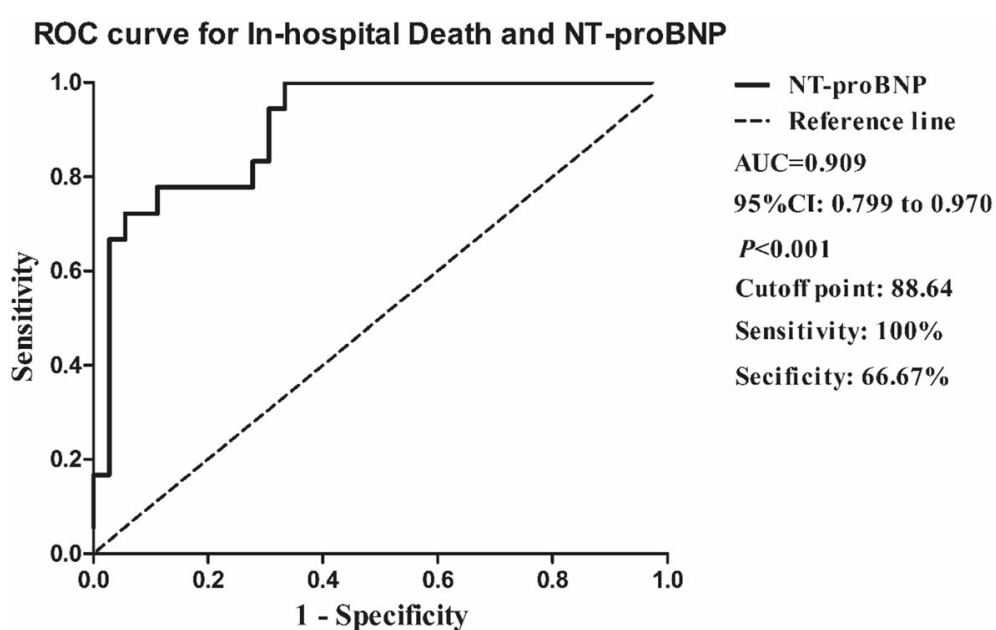

Fig. 1 The NT-proBNP for in-hospital death of coronavirus disease 2019 (COVID-19) by receiver operating characteristic (ROC) curves. The area under the curve (AUC) of NT-proBNP was 0.909. The best cutoff of NT-proBNP for prediction in-hospital death was $88.64 \mathrm{pg} / \mathrm{mL}$ with the sensitivity of $100 \%$ and the specificity of $66.67 \% .95 \% \mathrm{Cl}, 95 \%$ confidence interval 


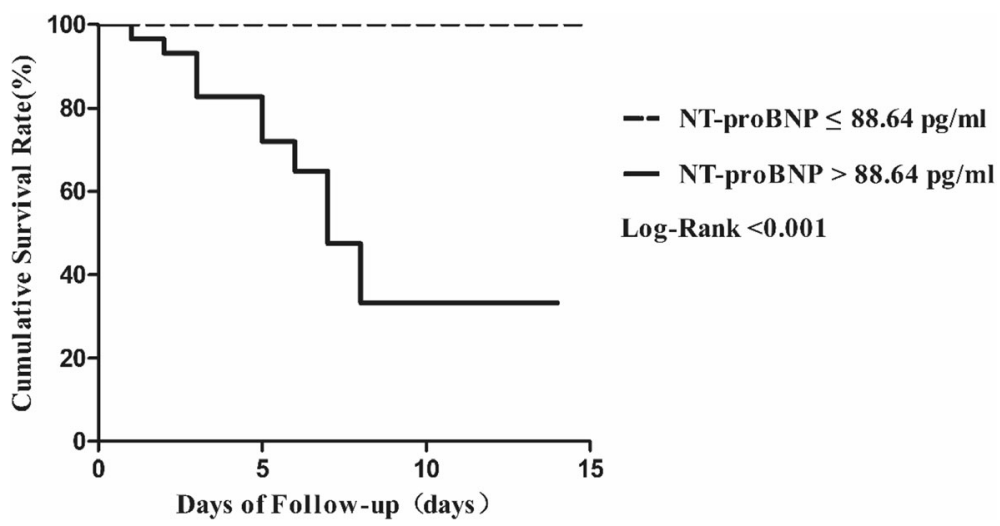

Fig. 2 Kaplan-Meier plots showing the cumulative survival rate of COVID-19 patients who were stratified into two groups according to plasma NT-proBNP cutoff point at baseline. Dotted line, NT-proBNP $\leq 88.64 \mathrm{pg} / \mathrm{ml}, n=24$; Solid line, NT-proBNP $>88.64 \mathrm{pg} / \mathrm{ml}, n=30$; log-rank test for trend, $P<0.001)$

Fig. 2. Patients in high NT-proBNP $(>88.64 \mathrm{pg} / \mathrm{mL})$ group had a significantly higher risk of death during the days of following-up than the low group (NT-proBNP $\leq 88.64 \mathrm{pg}$ / $\mathrm{mL}$ ) (Fig. 2).

\section{Spearman correlation coefficients of NT-proBNP with selected covariates}

In present study, plasma NT-proBNP was positively correlated with age, urea, cardiac injury markers of MYO, CK-MB and hs-TnI and systematic inflammation makers of WBC, CRP, Hs-CRP and PCT (Supplemental Table. 1).

\section{Results of cox proportional hazards analyses of in- hospital death}

Cox proportional hazards regression analysis was used to evaluate potential associations between NT-proBNP and in-hospital death. Results of univariate analyses showed that the hazard ratio (HR) of NT-proBNP associated to in-hospital death was 1.369 (95\% CI 1.217$1.541, P<0.001)$ for an increase of $100 \mathrm{pg} / \mathrm{mL}$. Meanwhile, age, male, history of hypertension (HP), myoglobin (MYO), creatine kinase-MB (CK-MB), high-sensitivity troponin-I (Hs-TnI), urea, creatinine, white blood cell (WBC), lymphocytes (LYM), c-reactive protein (CRP) and procalcitonin (PCT) were correlated with the risk of inhospital death (Table 2).

Multivariate Cox proportional hazards regression analyses were used to evaluate the independent prognostic effect of NT-proBNP level. After adjusting for sex and age (Mode 1), the HR of NT-proBNP for in-hospital death was 1.323 (95\% CI 1.119-1.563, $P=0.001)$ for an increase of $100 \mathrm{pg} / \mathrm{mL}$. After adjusting for HP and CHD history (Mode 2), the HR was 1.342 (95\% CI 1.1851.520, $P<0.001)$. After adjusting for MYO, CK-MB and hs-TNI (Mode 3), the HR was 1.360 (95\% CI 1.1771.572, $P<0.001)$. After adjusting for urea and creatinine
Table 2 Results of univariate Cox proportional-hazards regression analyzing the effect of baseline variables on inhospital death

\begin{tabular}{|c|c|c|c|}
\hline \multicolumn{2}{|l|}{ Characteristics } & \multirow{2}{*}{$\begin{array}{l}\mathrm{HR}(95 \% \mathrm{Cl}) \\
-\end{array}$} & \multirow[t]{2}{*}{$P$} \\
\hline Sex & Male & & \\
\hline & Female & $0.348(0.130-0.930)$ & 0.035 \\
\hline \multicolumn{2}{|l|}{ Age, per 10 years } & $1.975(1.309-2.981)$ & 0.001 \\
\hline \multirow[t]{2}{*}{ History of HP } & no & - & - \\
\hline & yes & $4.044(1.604-10.200)$ & 0.003 \\
\hline \multirow[t]{2}{*}{ History of CHD } & no & - & - \\
\hline & yes & $2.652(0.992-7.092)$ & 0.052 \\
\hline \multirow[t]{2}{*}{ History of COPD } & no & - & - \\
\hline & yes & $4.127(0.945-18.024)$ & 0.059 \\
\hline \multirow[t]{2}{*}{ History of DM } & no & - & - \\
\hline & yes & $0.958(0.277-3.314)$ & 0.947 \\
\hline \multicolumn{2}{|c|}{ NT-proBNP, per 100 pg/ml } & $1.369(1.217-1.541)$ & $<0.001$ \\
\hline \multicolumn{2}{|l|}{ MYO, per $1 \mathrm{ng} / \mathrm{ml}$} & $1.006(1.003-1.008)$ & $<0.001$ \\
\hline \multicolumn{2}{|l|}{ CK-MB, per $1 \mu \mathrm{g} / \mathrm{L}$} & $1.259(1.098-1.443)$ & 0.001 \\
\hline \multicolumn{2}{|l|}{ Hs-Tnl, per $1 \mathrm{ng} / \mathrm{ml}$} & $1.862(1.273-2.722)$ & 0.001 \\
\hline \multicolumn{2}{|c|}{ Urea, per $1 \mathrm{mmol} / \mathrm{L}$} & $1.134(1.073-1.198)$ & $<0.001$ \\
\hline \multicolumn{2}{|c|}{ Creatinine, per 1 umol/L } & $1.028(1.013-1.043)$ & $<0.001$ \\
\hline \multicolumn{2}{|c|}{ WBC, per $1 \times 10^{9} / \mathrm{L}$} & $1.150(1.076-1.229)$ & $<0.001$ \\
\hline \multicolumn{2}{|l|}{ LYM, per $1 \times 10^{9} / \mathrm{L}$} & $0.065(0.017-0.249)$ & $<0.001$ \\
\hline \multicolumn{2}{|l|}{ CRP, per $1 \mathrm{mg} / \mathrm{L}$} & $1.021(1.012-1.030)$ & $<0.001$ \\
\hline \multicolumn{2}{|l|}{$\mathrm{PCT}$, per $0.1 \mathrm{ng} / \mathrm{ml}$} & $1.241(1.142-1.349)$ & $<0.001$ \\
\hline
\end{tabular}

Abbreviations: HP Hypertension, CHD Coronary heart disease, COPD Chronic obstructive pulmonary disease, DM Diabetes mellitus, NT-proBNP N-terminal pro-brain natriuretic peptide, MYO Myoglobin, CK-MB Creatine kinase-MB, HsTnl High-sensitivity troponin-I, WBC White blood cell, LYM Lymphocytes, CRP Creactive protein, $P C T$ Procalcitonin, $H R$ hazards ratio, $95 \% \mathrm{Cl}$ 95\% confidence interval 
(Mode 4), the HR was 1.373 (95\% CI 1.188-1.586, $P<$ 0.001). After adjusting for WBC and LYM (Mode 5), the HR was 1.248 (95\% CI 1.097-1.419, $P=0.001)$. After adjusting for WBC, LYM and CRP (Mode 6), the HR was 1.230 (95\% CI 1.003-1.509, $P=0.047)$. After adjusting for WBC, LYM and PCT (Mode 7), the HR was 1.200 (95\% CI 1.045-1.380, $P=0.010$ ). In the process, the HRs of WBC and PCT in Mode 5 and 7 also showed significance for independently predicting in-hospital death while LYM show protective effect (Table 3, Fig. 3).

\section{Discussion}

The present study for the first time showed the relationship between plasma NT-proBNP level and the risk of in-hospital death in severe COVID-19 patients. Severe COVID-19 patients with high NT-proBNP levels tended to be older with increased cardiac injury markers and higher levels of systematic inflammation markers. Patients with high NT-proBNP (> 88.64 pg/mL) level had lower cumulative survival rate. After adjusting for potential cofounders in separate modes, NT-proBNP presented as an independent risk factor of in-hospital death in patients with severe COVID-19.

Previous studies have found that NT-proBNP is a powerful and independent predictor of mortality in community-acquired pneumonia (CAP) [8-10]. In these studies, the best cut-off values of NT-proBNP for prediction 30 -day mortality were $1434.5 \mathrm{pg} / \mathrm{mL}$ and $1795.5 \mathrm{pg} /$ $\mathrm{mL}$, respectively $[8,10]$. The elevated NT-proBNP in these cases was believed owing to the cardiac complications resulted from complex interactions among preexisting conditions, relative ischemia, up-regulation of the sympathetic system, systemic inflammation and direct pathogenmediated damage to the cardiovascular system [11].

However, the cutoff value of NT-proBNP to predict the adverse outcome of severe COVID-19 patients was far lower than the threshold to diagnose heart failure $(450 \mathrm{pg} / \mathrm{mL}$ for < 50 years, $900 \mathrm{pg} / \mathrm{mL}$ for $50-75$ years and $1800 \mathrm{pg} / \mathrm{mL}$ for $>75$ years) [12] in present study. It was suggested that the prognostic effect of plasma NTproBNP in severe COVID-19 patients could not fully ascribe to heart failure induced by the virus or hypoxia. Further understanding of physiological and pathological significance of plasma NT-proBNP elevation in severe COVID-19 patients might help clinicians make corresponding decisions to reduce the risks of adverse outcome.

$\mathrm{NT}$-proBNP is secreted in response to increased myocardial wall stress [13]. It is also controlled by acute renal injury and proinflammatory molecules such as lipopolysaccharide, interleukin 1, C-reactive protein, and cardiotrophin I, which are independent of ventricular function $[14,15]$. It was consisted with the study finding that NT-proBNP level was positively correlated to the makers of cardiac injury, renal injury and systematic inflammation. And these makers also constituted the risks of in-hospital death according to the univariate Cox proportional-hazards regression analysis. However, NTproBNP was an independent risk factor after accounting these factors in multivariate Cox. The prognostic effect of NT-proBNP might be a specific index of reflecting the overall state of SARS-CoV-2 infection.

Table 3 Results of multivariate Cox proportional-hazards regression analyzing the effect of baseline variables on inhospital death

\begin{tabular}{lll}
\hline Mode & HR $(95 \% \mathrm{Cl})$ & $P$ \\
\hline Not Adjusted NT-proBNP, per $100 \mathrm{pg} / \mathrm{ml}$ & $1.369(1.217-1.541)$ & $<0.001$ \\
Mode 1 & & \\
$\quad$ NT-proBNP, per $100 \mathrm{pg} / \mathrm{ml}$ & $1.323(1.119-1.563)$ & 0.001 \\
Female vs. Male & $1.077(0.330-3.518)$ & 0.902 \\
Age, per 10 years & $1.176(0.719-1.922)$ & 0.518
\end{tabular}

\section{Mode 2}

NT-proBNP, per $100 \mathrm{pg} / \mathrm{ml}$

$1.342(1.185-1.520)<0.001$

$H P$, yes vs. no

$1.613(0.591-4.406) \quad 0.351$

CHD, yes vs. no

$1.219(0.422-3.521) \quad 0.714$

Mode 3

NT-proBNP, per $100 \mathrm{pg} / \mathrm{m}$

$1.360(1.177-1.572)<0.001$

MYO, per $1 \mathrm{ng} / \mathrm{ml}$

$1.001(0.996-1.005) \quad 0.773$

CK-MB, per $1 \mu \mathrm{g} / \mathrm{L}$

$1.119(0.905-1.385) \quad 0.299$

Hs-Tnl, per $0.1 \mathrm{ng} / \mathrm{ml}$

$1.031(0.574-1.855)$ 0.918

Mode 4

NT-proBNP, per 100 pg/ml

$1.373(1.188-1.586)$

$<0.001$

Urea, per $1 \mathrm{mmol} / \mathrm{L}$

$1.041(0.936-1.158) \quad 0.460$

Creatinine, per 1 umol/L

$0.999(0.974-1.025)$

0.957

Mode 5

NT-proBNP, per $100 \mathrm{pg} / \mathrm{ml}$

$1.248(1.097-1.419)$

0.001

WBC, per $1 \times 10^{9} / \mathrm{L}$

$1.099(1.015-1.190)$

LYM, per $1 \times 10^{9} / \mathrm{L}$

$0.163(0.035-0.761)$

0.021

Mode 6

NT-proBNP, per $100 \mathrm{pg} / \mathrm{ml}$
WBC, per $1 \times 10^{9} / \mathrm{L}$
LYM, per $1 \times 10^{9} / \mathrm{L}$
CRP, per $1 \mathrm{mg} / \mathrm{L}$

$1.230(1.003-1.509)$

0.047

$1.036(0.903-1.189)$

0.611

$0.201(0.033-1.221)$

0.081

Mode 7

$$
\begin{aligned}
& \text { NT-proBNP, per } 100 \mathrm{pg} / \mathrm{ml} \\
& \text { WBC, per } 1 \times 10^{9} / \mathrm{L} \\
& \text { LYM, per } 1 \times 10^{9} / \mathrm{L} \\
& \text { PCT, per } 0.1 \mathrm{ng} / \mathrm{ml}
\end{aligned}
$$

$1.011(0.999-1.023)$

0.066

Abbreviations: NT-proBNP N-terminal pro-brain natriuretic peptide, $H P$ Hypertension, CHD Coronary heart disease, MYO Myoglobin, CK-MB Creatine kinase-MB, Hs-Tnl High-sensitivity troponin-I, WBC White blood cell, LYM Lymphocytes, CRP C-reactive protein, PCT Procalcitonin, HR Hazards ratio; $95 \% \mathrm{Cl} 95 \%$ confidence interval 


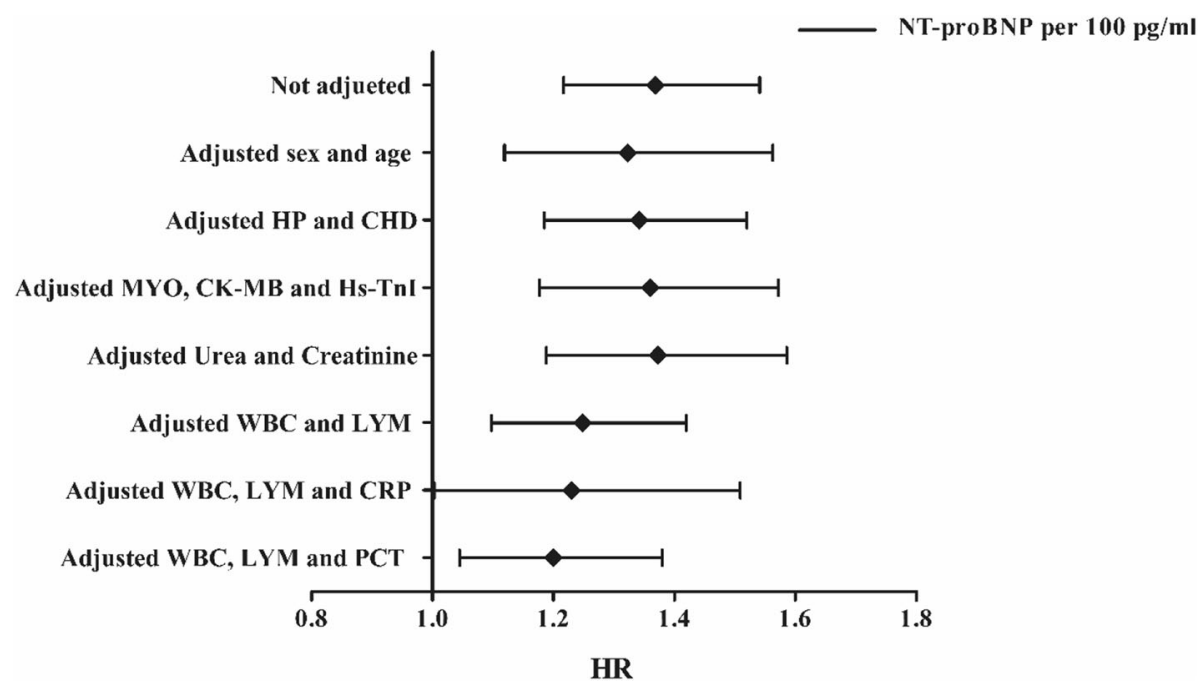

Fig. 3 Forest plots of multivariate Cox proportional-hazards regression analyzing the effect of baseline variables on in-hospital death. HP, hypertension; CHD, coronary heart disease; MYO, myoglobin; CK-MB, creatine kinase-MB; Hs-Tnl, high-sensitivity troponin-l; WBC, white blood cell; LYM, lymphocytes; CRP, c-reactive protein; PCT, procalcitonin; HR, hazards ratio

The mechanism of SARS-CoV-2-induced cardiac injury was still unclear. From the result of autopsy by $\mathrm{Xu}$ and colleagues, a few interstitial mononuclear inflammatory infiltrates were observed in heart biopsy, indicating an inflammation induced cardiac injury [16]. Other factors including the SARS-CoV-2 infection and invasion cardiomyocytes via the binding site of angiotensin-converting enzyme-related carboxypeptidase (ACE2) [17], the pulmonary infection induced inadequate oxygen supply to the myocardium and the influences of cytokine storm syndrome [18-20] might also contribute to the cardiac injury [21]. All these contributes to the elevation of NT-proBNP and risks of poor prognosis in patients with COVID-19.

The virus itself may also elevate the NT-proBNP level in COVID-19 patients. SARS-CoV-2 binds with ACE2, resulting the uncontrolled releasing of angiotensin 2 (ANGII) and restricted synthesis of ANG1-7 [22]. The latter exerts anti-inflammation effect to protect tissue while ANGII plays in an opposite role and facilitates the secretion of NT-proBNP [22-24]. It indicated that NT-proBNP level might associated with the severity of infection thus leading an adverse outcome, which needs further verification.

By investigating the prognostic effect of NT-proBNP level of severe COVID-19 patients at admission, it might be helpful to early identifying patients with poor prognoses. However, this study was limited by sample size and a single test of NT-proBNP at admission. Larger studies with continuous monitoring of NT-proBNP are necessary to further confirm the prognostic effect of NTproBNP in patients with severe COVID-19.

\section{Conclusion}

In conclusion, NT-proBNP might be an independent risk factor for in-hospital death in patients with severe COVID-19.

\section{Supplementary information}

Supplementary information accompanies this paper at https://doi.org/10. 1186/s12931-020-01352-w.

Additional file 1: Table S1. Spearman correlation coefficients of

NT-proBNP with selected covariates.

\section{Abbreviations}

COVID-19: Coronavirus disease 2019; SARS-CoV-2: Severe acute respiratory syndrome coronavirus 2; ROC: Receiver operation characteristic; HR: Hazard ratio; CAP: Community-acquired pneumonia; SBP: Systolic blood pressure; DBP: Diastolic blood pressure; HP: Hypertension; CHD: Coronary heart disease; COPD: Chronic obstructive pulmonary disease; DM: Diabetes mellitus; NT-proBNP: N-terminal pro-brain natriuretic peptide;

MYO: Myoglobin; CK-MB: Creatine kinase-MB; Hs-Tnl: High-sensitivity troponin-I; WBC: White blood cell; LYM: Lymphocytes; CRP: C-reactive protein; PCT: Procalcitonin; ACE2: Angiotensin-converting enzyme-related carboxypeptidase; ANG: Angiotensin

\section{Acknowledgements}

We thank all the staffs working at the front-line to battle against SARS-CoV-2. We thank Doctor Liu Z.M. who worked at Hubei General Hospital for his great help concerning the current study.

\section{Author's contributions}

G.L. and J.D. contributed to the study design, analyzing data and preparation manuscript. W.X., C.X., S.M., H.B., Y.L., L.P. and T.X. were involved in the acquisition of data. Q.S., C.G. and Z.D. worked on the study concept, design and final proof. All authors read and approved the final manuscript.

\section{Funding}

National Natural Science Foundation of China, 81570212; National Natural Science Foundation of China, 31800976; Chongqing Science and Health Joint Medical Research Project, 2018QNXM024. 


\section{Availability of data and materials}

The raw data required to reproduce these findings cannot be shared at this time as the data also forms part of an ongoing study.

\section{Ethics approval and consent to participate}

The study has been performed in accordance with the Declaration of Helsinki and was approved by the Ethics Committee of the First Affiliated Hospital of Chongqing Medical University (Grant No. 20200701). All subjects were well informed.

\section{Consent for publication}

Not applicable.

\section{Competing interests}

The authors declare no conflict of interest.

\section{Author details}

'Department of Cardiovascular Medicine, The First Affiliated Hospital of Chongqing Medical University, Chongqing 400016, China. ${ }^{2}$ Department of Cardiovascular Medicine, The First Branch of the First Affiliated Hospital of Chongqing Medical University, Chongqing 400016, China. ${ }^{3}$ Traditional Chinese Medicine hospital Dianjiang Chongqing, Chongqing 408300, China.

Received: 11 March 2020 Accepted: 2 April 2020

Published online: 15 April 2020

\section{References}

1. Lai C-C, Shih T-P, Ko W-C, Tang H-J, Hsueh P-R. Severe acute respiratory syndrome coronavirus 2 (SARS-CoV-2) and corona virus disease-2019 (COVID-19): the epidemic and the challenges. Int J Antimicrob Agents. 2020: 105924-4. https://doi.org/10.1016/j.ijantimicag.2020.105924.

2. Mahase E. Coronavirus covid-19 has killed more people than SARS and MERS combined, despite lower case fatality rate. BMJ. 2020;368:m641. https://doi.org/10.1136/bmj.m641.

3. Huang C, et al. Clinical features of patients infected with 2019 novel coronavirus in Wuhan, China. Lancet. 2020;395:497-506. https://doi.org/10. 1016/s0140-6736(20)30183-5.

4. Guan WJ, et al. Clinical characteristics of coronavirus disease 2019 in China. N Engl J Med. 2020. https://doi.org/10.1056/NEJMoa2002032.

5. Shi S, et al. Association of Cardiac Injury with mortality in hospitalized patients with COVID-19 in Wuhan, China. JAMA Cardiol. 2020. https://doi. org/10.1001/jamacardio.2020.0950.

6. Guo T, et al. Cardiovascular implications of fatal outcomes of patients with coronavirus disease 2019 (COVID-19). JAMA Cardiol. 2020. https://doi.org/10. 1001/jamacardio.2020.1017.

7. Wang D, et al. Clinical Characteristics of 138 Hospitalized Patients With 2019 Novel coronavirus-infected pneumonia in Wuhan, China. Jama. 2020. https://doi.org/10.1001/jama.2020.1585.

8. Jeong $\mathrm{KY}$, et al. Prognostic value of $\mathrm{N}$-terminal pro-brain natriuretic peptide in hospitalised patients with community-acquired pneumonia. Emerg Med J. 2011;28:122-7. https://doi.org/10.1136/emj.2009.089383.

9. Fernandez JF, Restrepo MI. Is N-terminal pro-B-type natriuretic peptide ready for 'prime time' in severe pneumonia? Respirology. 2013;18:889-90. https://doi.org/10.1111/resp.12134.

10. Akpınar $\mathrm{EE}$, et al. Do N-terminal pro-brain natriuretic peptide levels determine the prognosis of community acquired pneumonia? J Bras Pneumol. 2019;45:e20180417. https://doi.org/10.1590/1806-3713/e20180417.

11. Restrepo MI, Reyes LF. Pneumonia as a cardiovascular disease. Respirology. 2018;23:250-9. https://doi.org/10.1111/resp.13233.

12. Hill SA, et al. Use of BNP and NT-proBNP for the diagnosis of heart failure in the emergency department: a systematic review of the evidence. Heart Fail Rev. 2014;19:421-38. https://doi.org/10.1007/s10741-014-9447-6.

13. Saenger AK, et al. Specificity of B-type natriuretic peptide assays: crossreactivity with different BNP, NT-proBNP, and proBNP peptides. Clin Chem. 2017;63:351-8. https://doi.org/10.1373/clinchem.2016.263749.

14. Shor $\mathrm{R}$, et al. BNP in septic patients without systolic myocardial dysfunction. Eur J Intern Med. 2006;17:536-40.

15. Vallabhajosyula $\mathrm{S}$, et al. Natriuretic peptides to predict short-term mortality in patients with sepsis: a systematic review and meta-analysis. Mayo Clin Proc Innov Qual Outcomes. 2020:4:50-64. https://doi.org/10.1016/j. mayocpiqo.2019.10.008.
16. Xu Z, et al. Pathological findings of COVID-19 associated with acute respiratory distress syndrome. Lancet Respir Med. 2020. https://doi.org/10. 1016/S2213-2600(20)30076-X.

17. Donoghue $\mathrm{M}$, et al. A novel angiotensin-converting enzyme-related carboxypeptidase (ACE2) converts angiotensin I to angiotensin 1-9. Circ Res. 2000;87:E1-9. https://doi.org/10.1161/01.res.87.5.e1.

18. Chen C, Zhang XR, Ju ZY, He WF. Advances in the research of cytokine storm mechanism induced by Corona virus disease 2019 and the corresponding immunotherapies. Zhonghua Shao Shang Za Zhi. 2020;36: E005. https://doi.org/10.3760/cma.j.cn501120-20200224-00088.

19. Xu K, et al. Management of corona virus disease-19 (COVID-19): the Zhejiang experience. Zhejiang Da Xue Xue Bao Yi Xue Ban. 2020;49:0.

20. Tetro JA. Is COVID-19 receiving ADE from other coronaviruses? Microbes Infect. 2020;S1286-4579(1220):30034. https://doi.org/10.1016/j.micinf.2020. 02.006 .

21. Wei ZY, Qian HY. Myocardial injury in patients with COVID-19 pneumonia. Zhonghua Xin Xue Guan Bing Za Zhi. 2020;48:E006. https://doi.org/10.3760/ cma.j.issn.cn112148-20200220-00106.

22. Zhang H, Penninger JM, Li Y, Zhong N, Slutsky AS. Angiotensin-converting enzyme 2 (ACE2) as a SARS-CoV-2 receptor: molecular mechanisms and potential therapeutic target. Intensive Care Med. 2020. https://doi.org/10. 1007/s00134-020-05985-9 https://doi.org/10.1007/s00134-00020-0598500139.

23. Santos RAS, et al. The ACE2/angiotensin-(1-7)/MAS Axis of the reninangiotensin system: focus on angiotensin-(1-7). Physiol Rev. 2018;98:505-53. https://doi.org/10.1152/physrev.00023.2016.

24. Patel VB, Zhong J-C, Grant MB, Oudit GY. Role of the ACE2/Angiotensin 1-7 Axis of the Renin-Angiotensin System in Heart Failure. Circ Res. 2016;118: 1313-26. https://doi.org/10.1161/CIRCRESAHA.116.307708.

\section{Publisher's Note}

Springer Nature remains neutral with regard to jurisdictional claims in published maps and institutional affiliations.

Ready to submit your research? Choose BMC and benefit from:

- fast, convenient online submission

- thorough peer review by experienced researchers in your field

- rapid publication on acceptance

- support for research data, including large and complex data types

- gold Open Access which fosters wider collaboration and increased citations

- maximum visibility for your research: over $100 \mathrm{M}$ website views per year

At BMC, research is always in progress.

Learn more biomedcentral.com/submissions 